\title{
REVIEW
}

\section{Vegas (Verruciform Genital-Associated) Xanthoma: A Comprehensive Literature Review}

Katherine M. Stiff · Philip R. Cohen

Received: September 23, 2016 / Published online: November 15, 2016

(C) The Author(s) 2016. This article is published with open access at Springerlink.com

\begin{abstract}
Introduction: Verruciform xanthoma is a wart-like benign lesion. The classic histologic appearance consists of foamy histiocytes within elongated dermal papillae and epithelial acanthosis. The lesion most commonly occurs in the oral cavity, but has been reported in extra-oral sites such as the penis, scrotum, and vulva. The clinical and histologic characteristics of verruciform genital-associated (Vegas) xanthomas of the penis, scrotum, and vulva are reviewed.
\end{abstract}

Methods: PubMed was used to search the following term: verruciform xanthoma. The relevant papers were obtained and reviewed.

Results: There have been 193 cases of genital-associated verruciform xanthomas.

Enhanced content To view enhanced content for this article go to http://www.medengine.com/Redeem/951 7F0603C08B0DA.

K. M. Stiff ( $\square)$

Northeast Ohio Medical University, Rootstown, $\mathrm{OH}$, USA

e-mail: katherinestiff@gmail.com

P. R. Cohen $(\bowtie)$

Department of Dermatology, University of

California San Diego, La Jolla, CA, USA

e-mail: mitehead@gmail.com
There were 164 in men and 29 in women. Similar to verruciform xanthomas of the oral mucosa, they presented as asymptomatic lesions, demonstrated foam cells in the dermal papillae, and were typically managed successfully with surgical excision.

Conclusion: Verruciform xanthoma is a benign lesion characterized by a wart-like growth that is most commonly seen in the oral mucosa. Verruciform xanthomas of the genital region have been coined Vegas xanthomas. Vegas xanthomas have been reported in association with a variety of diseases, as well as in healthy individuals. Biopsy is required for diagnosis, and complete surgical excision is typically curative.

Keywords: VEGAS xanthoma; Verruciform xanthoma; Verruciform xanthoma of the penis; Verruciform xanthoma of the scrotum; Verruciform xanthoma of the vulva

\section{INTRODUCTION}

Verruciform xanthoma is a benign tumor that typically occurs in the oral mucosa [1-86]. Extraoral lesions have been most commonly 
described on the penis (Table 1), scrotum (Table 2), and vulva (Table 3). Tumors in genital locations have recently been referred to as Vegas (Verruciform Genital-Associated) xanthomas [63]. The characteristics of verruciform xanthomas of the genitalia are reviewed. This article is based on previously conducted studies and does not involve any new studies of human or animal subjects performed by any of the authors.

\section{History}

Verruciform xanthoma is a wart-like lesion that most commonly occurs in the oral mucosa. It was first described as a xanthoma-like nevus by Sachs in 1903 [78]. In 1971, Shafer coined the term "verruciform xanthoma" while describing 15 cases in the oral cavity [64]. These lesions were reported as asymptomatic, pale or hyperkeratotic, with a pebbly surface and verrucous appearance. The most common extraoral verruciform xanthomas are reported in the genital region; however, other reported extra-oral locations include the anal region, ear, forearm, foot, hand, leg, nose, and sacrum [65-71, 74].

In 2003, Philipsen et al. did a profile of 282 oral verruciform xanthomas [79]. They found a slight male predominance below the age of 50 , with a male:female ratio of $1.6: 1$, and a slight female predominance above the age of 50 , with a male:female ratio of $0.8: 1 ; 73.4 \%$ of the oral verruciform xanthomas were on the masticatory mucosa. The majority of cases were reported in Caucasians (139 patients) and Japanese (109 patients), but there were also reports of African Americans, Asians, and South Americans [79].

\section{Differential Diagnosis}

Clinically, verruciform xanthomas have a similar appearance to bowenoid papulosis, condyloma acuminatum, erythroplasia of Queyrat, granular cell tumor, giant molluscum contagiosum, seborrheic keratosis, squamous cell carcinoma, verruca vulgaris, verrucous carcinoma, and vulvar intraepithelial neoplasia (Fig. 1) $[11,27,40,75,76]$. A biopsy is necessary to confirm the diagnosis of verruciform xanthoma.

The histologic differential diagnosis of verruciform xanthoma includes condyloma accuminatum, granular cell epulis, granular cell tumor, verruca vulgaris, and verrucous carcinoma [30]. The characteristic pathologic features of verruciform xanthoma allow it to be distinguished. These features include acanthotic epidermis with parakeratosis that extends deep into the epithelium, uniformly elongated rete ridges, neutrophilic infiltrate in the dermis, and foamy histiocytes throughout the dermal papillae (Fig. 2) [64]. The foam cells stain Periodic Acid Schiff-positive and express CD68 antigen, indicating the presence of glycogen granules in monocyte-macrophage lineage cells $[12,13,17,52,55]$.

\section{Pathogenesis}

The pathogenesis of verruciform xanthoma is unknown. The majority of patients with verruciform xanthomas do not have any systemic lipid abnormalities. It has been hypothesized that the lesions are associated with human papilloma virus [30], but multiple studies have found this association to be unlikely $[9,18,82,83]$.

Zegarelli et al. postulated that a local irritant leads to epithelial degradation that initiates an inflammatory response [81]. He states that the inflammatory response damages keratinocytes, which release lipids that are then engulfed by macrophages, leading to the accumulation of foam cells. Mohsin et al. found that damaged keratinocytes release cytokines that attract 
Table 1 Verruciform xanthomas of the penis

\begin{tabular}{|c|c|c|c|c|c|c|c|c|}
\hline Case & $\begin{array}{l}\text { AO } \\
\text { (year) }\end{array}$ & Duration & Race & Location & Morphology & Color & Size $^{a}$ & Ref. \\
\hline 1 & 8 & 25 years & I & $\mathrm{R}$ prepuce & $\mathrm{V}$, dry growth & Pinkish & NA & {$[39]$} \\
\hline 2 & 16 & $\mathrm{NA}$ & W & Penis & $\begin{array}{l}\text { Ps forming } \mathrm{v} \\
\text { plaque }\end{array}$ & E Y & $10-20 \mathrm{~mm}$ & {$[8]$} \\
\hline 3 & 22 & 3 months & NA & Prepuce & Ind plaque & R-orange & $2.5 \times 1.75 \mathrm{~cm}$ & {$[11]$} \\
\hline 4 & 23 & 5 years & NA & Glans penis & Firm, v, ib & Pink & $1.5 \mathrm{~cm}$ & {$[15]$} \\
\hline $5^{b}$ & 25 & NA & NA & NA & NA & NA & NA & {$[37]$} \\
\hline 6 & 28 & 2 weeks & $\mathrm{B}$ & Left penile shaft & Pn, ker & Y-brown & $15 \times 5 \mathrm{~mm}$ & {$[5]$} \\
\hline 7 & 29 & $\mathrm{NA}$ & W & Coronal sulcus & $\mathrm{v}$ & NA & $2.4 \times 1.7 \times 0.7 \mathrm{~cm}$ & {$[10]$} \\
\hline 8 & 38 & 2.5 months & W & Penile shaft perineum & Pn, $p$ & $\mathrm{E}$ & $8 \times 5 \mathrm{~mm}$ & {$[3]$} \\
\hline 9 & 39 & 6 months & W & Glans penis & $\mathrm{V}$, caul, soft & E with $\mathrm{Y}$ & $1.5 \times 1.5 \times 0.6 \mathrm{~cm}$ & {$[40]$} \\
\hline 10 & 40 & 12 years & $\mathrm{C}$ & $\mathrm{L}$ glans penis & Caul, v, ker & Y-brown & $4 \times 3.2 \mathrm{~cm}$ & {$[17]$} \\
\hline \multirow[t]{2}{*}{11} & 41 & $\mathrm{NA}$ & W & Glans penis & NA & NA & $2 \mathrm{~cm}$ & {$[13]$} \\
\hline & 57 & & & Whole penile shaft & Caul, foc ulc & $\mathrm{Y}$ & $7 \times 3 \mathrm{~cm}$ & \\
\hline 12 & 43 & 1 year & NA & Ventral shaft & Wl p & Pale brown & $0.8 \mathrm{~cm}$ & {$[45]$} \\
\hline 13 & 45 & NA & I & Inner prepuce & Flat, wl, p & NA & NA & {$[2]$} \\
\hline 14 & 52 & 1 year & W & Glans penis & NI, V plaque & W & $1.5 \times 0.5 \mathrm{~cm}$ & [6] \\
\hline 15 & 57 & 1.5 years & W & Glans penis & $\begin{array}{l}\text { Irreg surf, not } \\
\text { wl }\end{array}$ & $\mathrm{R}$ & $10 \mathrm{~mm}$ & {$[16]$} \\
\hline 16 & 56 & 5 years & NA & $\mathrm{NA}$ & $\mathrm{V}, \mathrm{p}$ & NA & $0.3 \mathrm{~cm}$ & {$[18]$} \\
\hline \multirow[t]{2}{*}{17} & 61 & NA & $\mathrm{J}$ & Inner prepuce & Ind, v plaque & Y-red & $\mathrm{NA}$ & {$[20]$} \\
\hline & 67 & & & $\begin{array}{l}\text { Coronal sulcus and } \\
\text { glans penis }\end{array}$ & $\begin{array}{l}\text { Ind, eroded } \\
\text { tumor }^{c}\end{array}$ & & & \\
\hline 18 & 62 & 2 years & W & Sulcus & P, well-def, wl & E-brownish & $1.5 \times 2 \mathrm{~cm}$ & {$[14]$} \\
\hline 19 & 64 & 2 years & & Prepuce & V lesion & NA & $\mathrm{NA}$ & {$[45]$} \\
\hline 20 & 64 & $\mathrm{NA}$ & W & Near coronal sulcus & NI, V plaque & $\mathrm{R}$ & $1.5 \times 2 \mathrm{~cm}$ & {$[7]$} \\
\hline 21 & 71 & NA & W & Foreskin & Firm, swollen & NA & $\mathrm{NA}$ & [9] \\
\hline 22 & 72 & 2 years & W & Glans penis & $G \& V$ & $\mathrm{R}$ to $\mathrm{Y}$ & $\mathrm{NA}$ & {$[1]$} \\
\hline 23 & 73 & $\mathrm{NA}$ & W & Inferior foreskin & $\mathrm{P}$ & $\begin{array}{l}\text { Pink to } \\
\text { brown }\end{array}$ & $6 \times 5 \times 2 \mathrm{~mm}$ & {$[4]$} \\
\hline 24 & 77 & NA & NA & Glans penis & Sessile, wl & NA & $1 \times 0.5 \mathrm{~cm}$ & {$[38]$} \\
\hline 25 & 77 & 10 months & W & Glans penis & $\mathrm{V}$ nodule & $\mathrm{Y}$ & $15 \times 12 \mathrm{~mm}$ & {$[12]$} \\
\hline 26 & 85 & 7 months & W & Distal foreskin & $\mathrm{V}$ plaque & Skin color & $1 \times 1.5 \mathrm{~cm}$ & [19] \\
\hline 27 & $\mathrm{NA}$ & NA & I & Coronal sulcus & Flat, wl, p & NA & NA & [2] \\
\hline
\end{tabular}


Table 1 continued

\begin{tabular}{lllllllll}
\hline Case & $\begin{array}{l}\text { AO } \\
\text { (year) }\end{array}$ & Duration & Race & Location & Morphology & Color & Size $^{\mathbf{a}^{2}}$ & Ref. \\
\hline 28 & NA & NA & NA & Glans penis & NA & NA & NA & {$[72]$} \\
$29^{\mathrm{d}}$ & NA & NA & NA & NA & NA & NA & NA & {$[77]$} \\
\hline
\end{tabular}

$A O$ age of onset, $B$ black, $C$ Chinese, caul cauliflower-like, def defined, $E$ erythematous, $F$ filiform, foc ulc focally ulcerated, $i b$ irregular boundaries, irreg irregular, $I$ Indian, ind indurated, $G \& V$ globules and small-dotted vessels, ker keratotic, $m$ months, $N A$ not available, $N I$ non-indurated, $p(s)$ papule(s), $p n$ pedunculated, $R$ red, Ref reference, sev several, surf surface, $v$ verrucous, $w$ white, $w k s$ weeks, $w l$ wart-like, $Y$ yellow, $y$ year

a Size is reported as given in the case reports. This is measured either in diameter, length $\times$ width, or length $\times$ width $\times$ height

b Kukreja et al. discuss a case of a 25 -year-old male who was circumcised for a penile lesion. The clinical features were unavailable. The lesion was initially misdiagnosed as a squamous cell carcinoma, but due to the histological features of the lesion, their department determined it was actually a verruciform xanthoma [37]

c The patient's original lesion was treated with circumcision; however, its removal from the coronary sulcus was suspected to be incomplete because of severe adhesion present between the prepuce and the glans penis. A yellowish-red papule was noted at the coronary sulcus 4 months following surgery. The patient decided not to have surgery because the lesion was reported to be benign. Six years later, the patient reported with an eroded tumor covering the entire coronary sulcus and much of the glans penis. This lesion was found to be a squamous cell carcinoma. The patient received a partial penectomy d Pellice et al. reported a verruciform xanthoma of the penis. No other information was obtained [77]

neutrophils and stimulate rapid growth of the epidermis, supporting Zegarelli et al.'s hypothesis [18].

Other investigators have speculated that verruciform xanthomas may be due to an immunologic reaction $[28,84,86]$. Oliveira et al. proposed that verruciform xanthomas are formed by an autoimmune reaction inducing apoptosis of epithelial cells, similarly to lichen planus [84]. This is supported by multiple cases of verruciform xanthomas reported in association with lichen planus $[43,85]$.

However, there is not sufficient evidence to conclude a clear mechanism of pathogenesis associated with verruciform xanthomas.

\section{Verruciform Xanthomas of the Penis (Table 1)}

The first verruciform xanthoma of the penis was reported in 1981 by Kraemer et al. [11]. To date, there are 31 cases of penile verruciform xanthomas in the literature that have been described in 29 men. The age of onset of the lesions ranged from 8 to 85 years, with a mean of 54.5 years. Most of the lesions occurred in Caucasians.

The duration of the penile verruciform xanthomas prior to establishing the diagnosis ranged from 2 weeks to 25 years, with a mean duration of 3.7 years. The locations (of the 27 lesions for which the site was specified) include the coronal sulcus $(18.5 \%, n=5)$, glans $(37.0 \%$, $n=10)$, prepuce $(29.6 \%, n=8)$, and shaft $(14.8 \%, n=4)$. The colors varied; including brown, erythematous, pink, and yellow.

Verruciform xanthomas of the penis have been reported following necrotizing fasciitis of the anogenital region [3], radical removal of initial verruciform xanthoma with grafting of the foreskin [13], and transurethral prostate resection [4].

\section{Verruciform Xanthomas of the Scrotum}

(Table 2)

The first scrotal verruciform xanthoma was described in 1984 by Al-Nafussi et al. [32]. Fukuda 


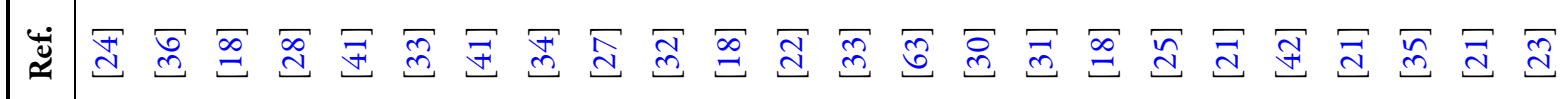

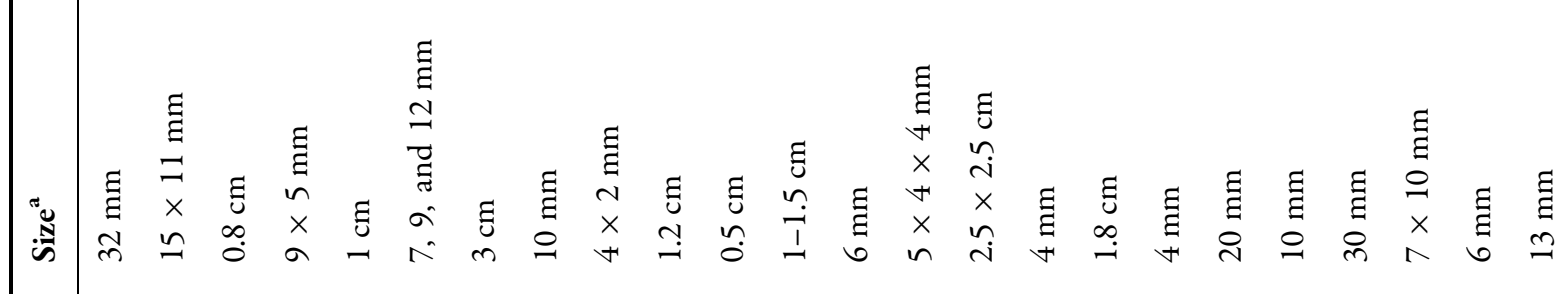

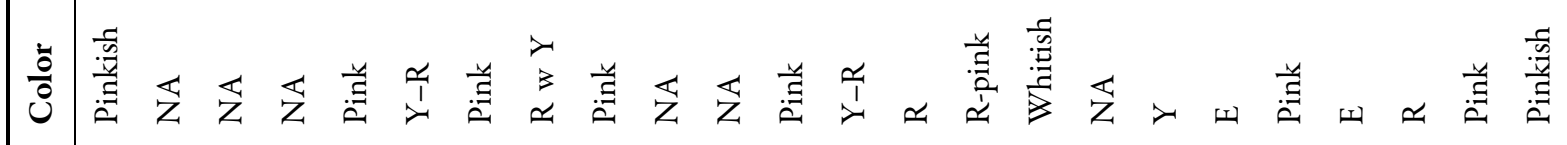

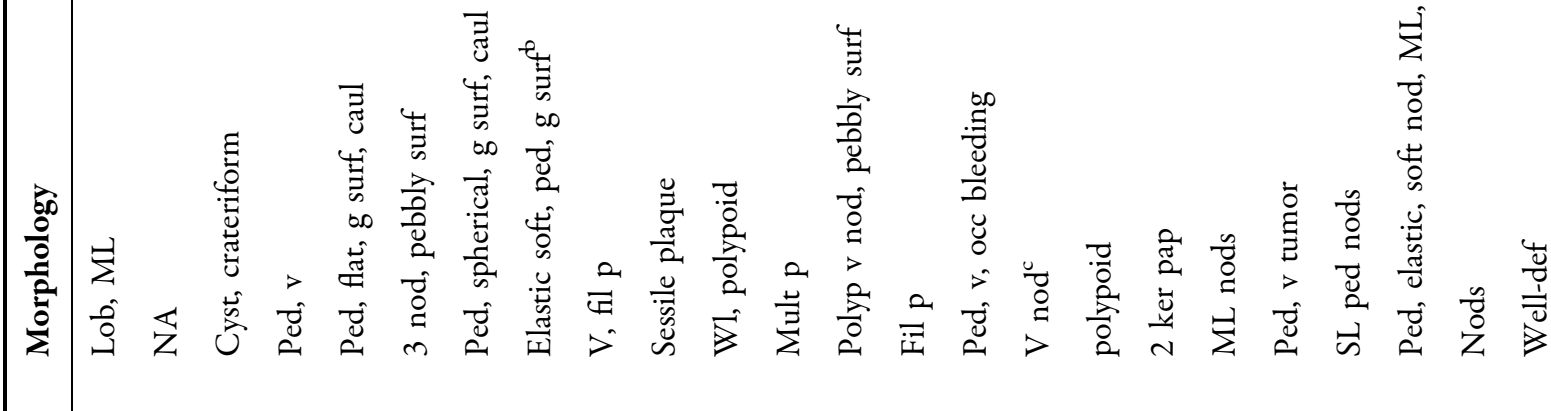
(ี)

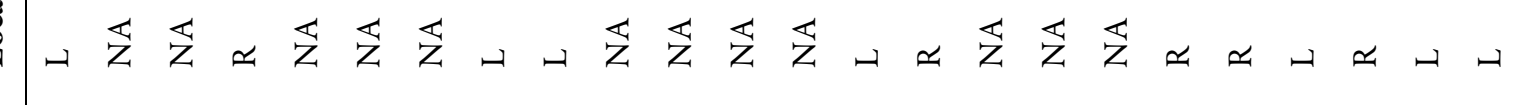

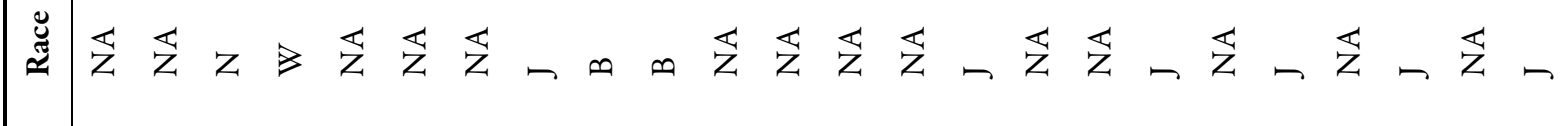
范

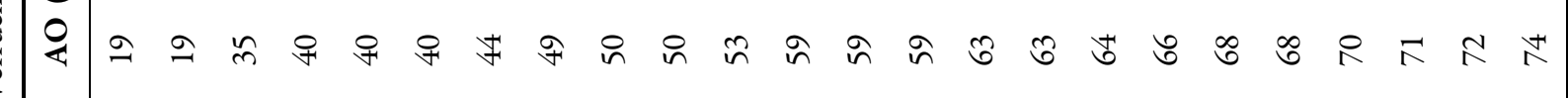
鄫。 


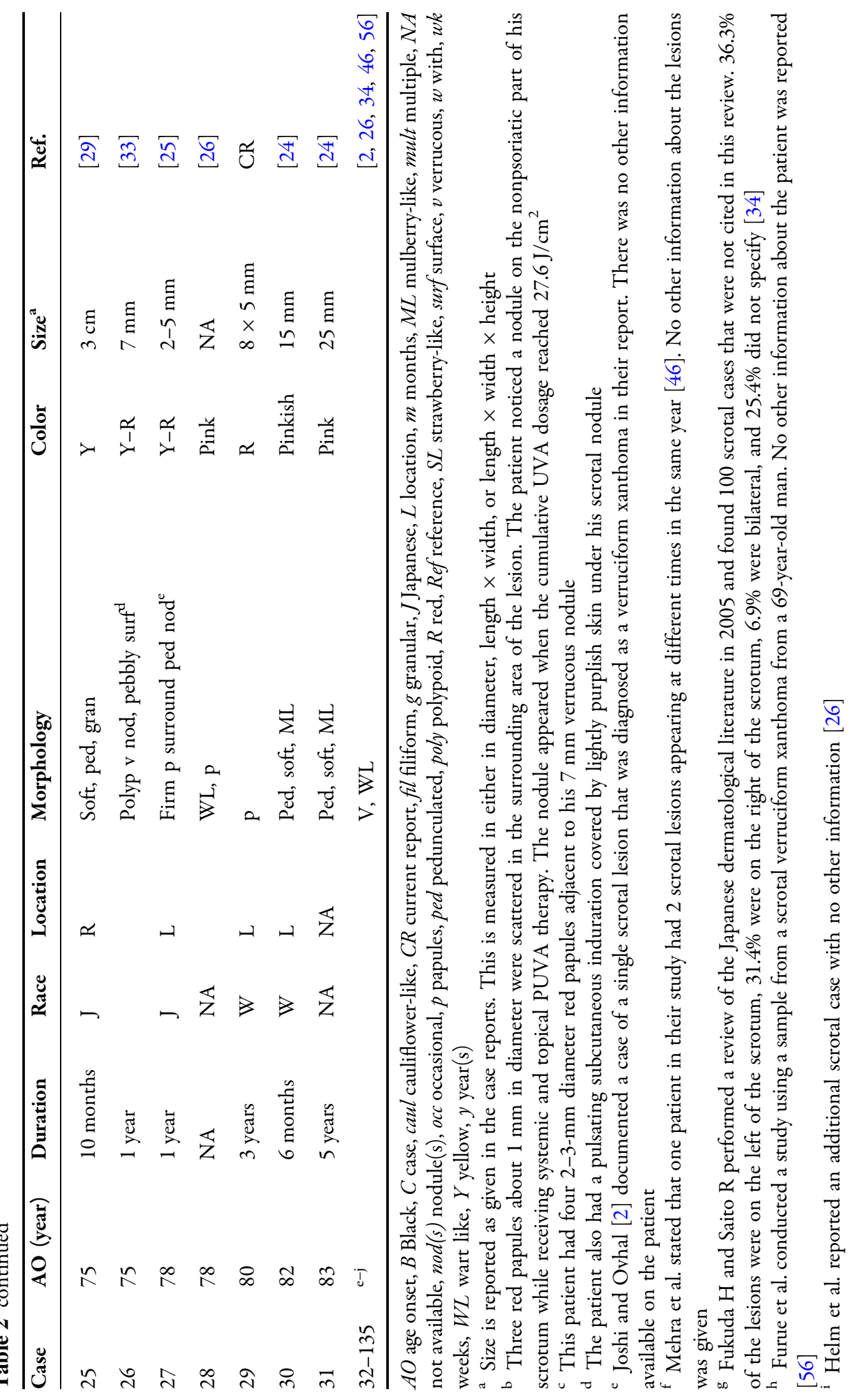




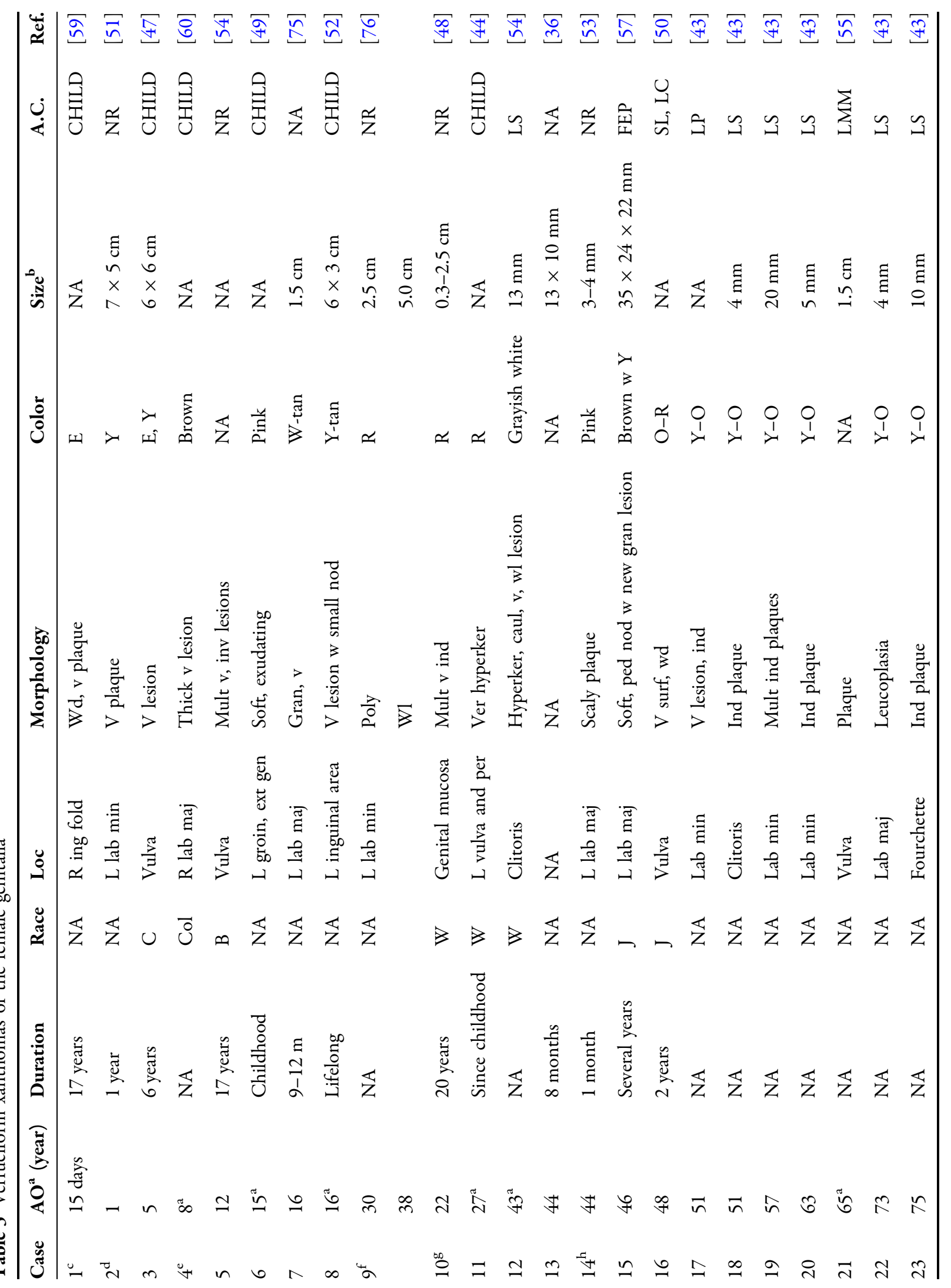




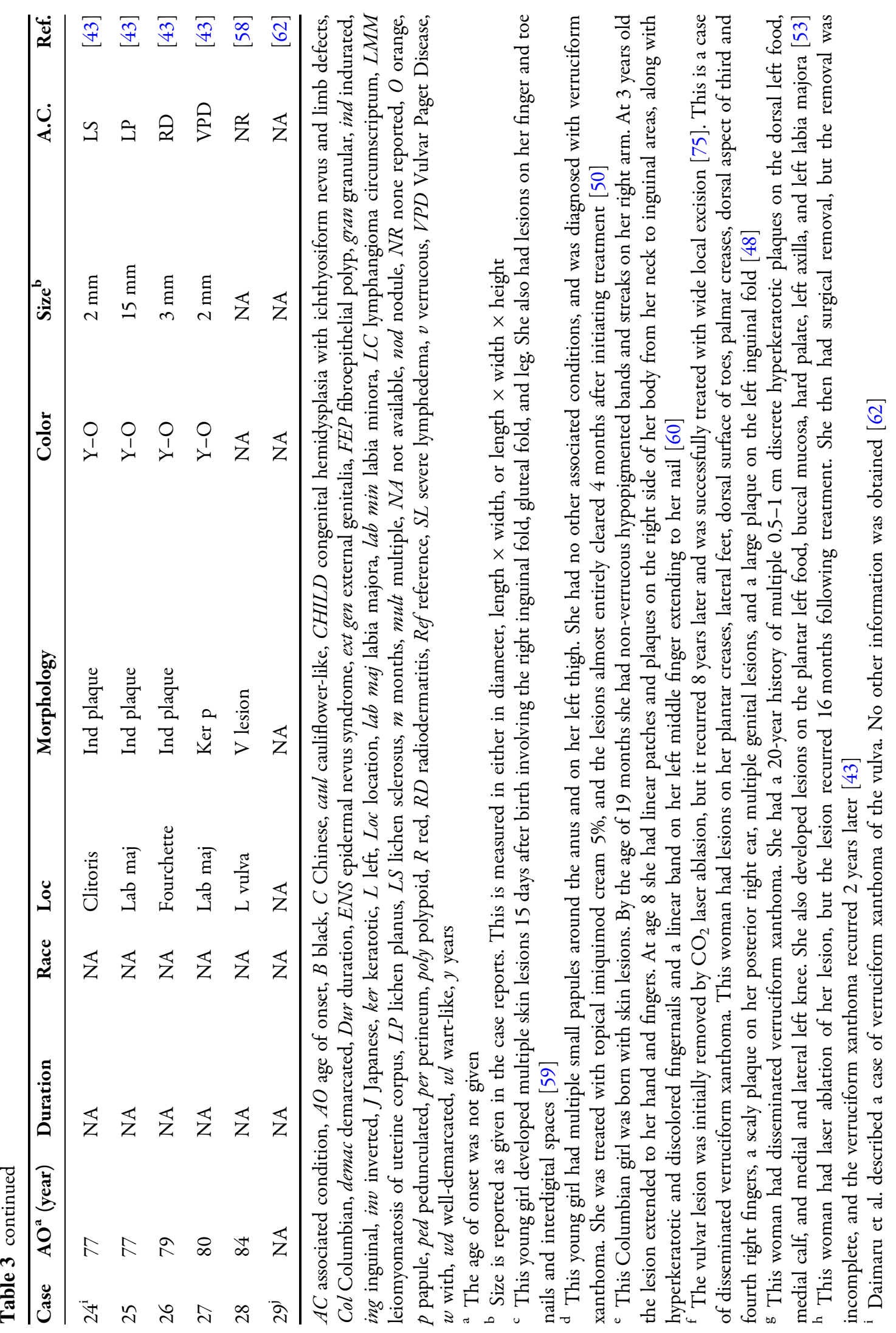



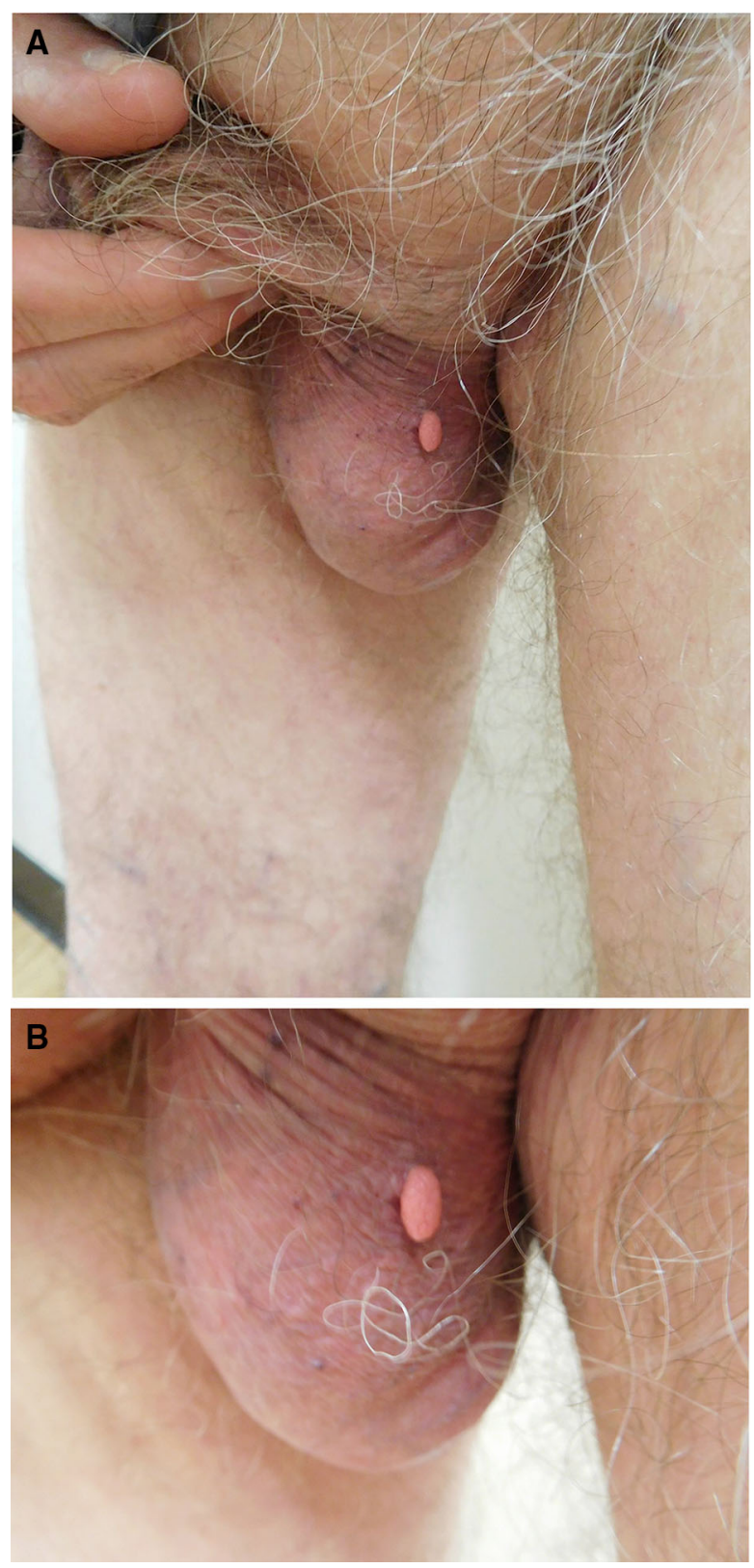

Fig. 1 Distant (a) and closer (b) views showing a pedunculated papule protruding from the patient's left side of the scrotum of an 83-year-old heterosexual monogamous man who had no history of sexually transmitted diseases and no reported HIV risk factors. He presented with an asymptomatic lesion of 3-year duration. Cutaneous examination revealed a flesh-colored $8 \times 5 \mathrm{~mm}$ wart-like elongated papule localized to the left side of his scrotum. A snip excision was performed for biopsy and removal of the lesion and Saito carried out a review of the Japanese literature and found that $81 \%$ of verruciform xanthomas in the pubic area were located on the scrotum [34]. Including the 102 cases reviewed by Fukuda and Saito, there have been 135 reported cases of scrotal verruciform xanthomas.

Kono suggested that the verruciform xanthomas may be related to irritation of the scrotum by the Japanese custom of sitting on the floor [80]. This is an interesting hypothesis since there is a significant number of scrotal verruciform xanthomas reported in the Japanese literature [34, 35, 42]. These findings support Zegarreli et al.'s proposal that verruciform xanthoma formation may be linked to epithelial degeneration due to irritation [81].

The age of onset was given for 26 of the scrotal lesions, and ranged from ages 19 to 83 years, with a mean age of 59.5 years. The duration of the tumors, prior to establishing the diagnosis, varied from 3 weeks to 20 years. The color of the tumor was most commonly pink.

Scrotal lesions have been associated with arteriovenous haemangioma [29], epidermolytic acanthoma [25, 34], graft versus host disease following bone marrow transplant for acute lymphoblastic leukemia [83], human papillomavirus [30], and psoriasis in a patient undergoing psoralen and ultraviolet A (PUVA) therapy [31]. One scrotal lesion was reported following a kidney transplant [28].

\section{Verruciform Xanthomas of the Inguinal Fold}

In addition to the scrotal and penile tumors, verruciform xanthoma of the genitalia has been 

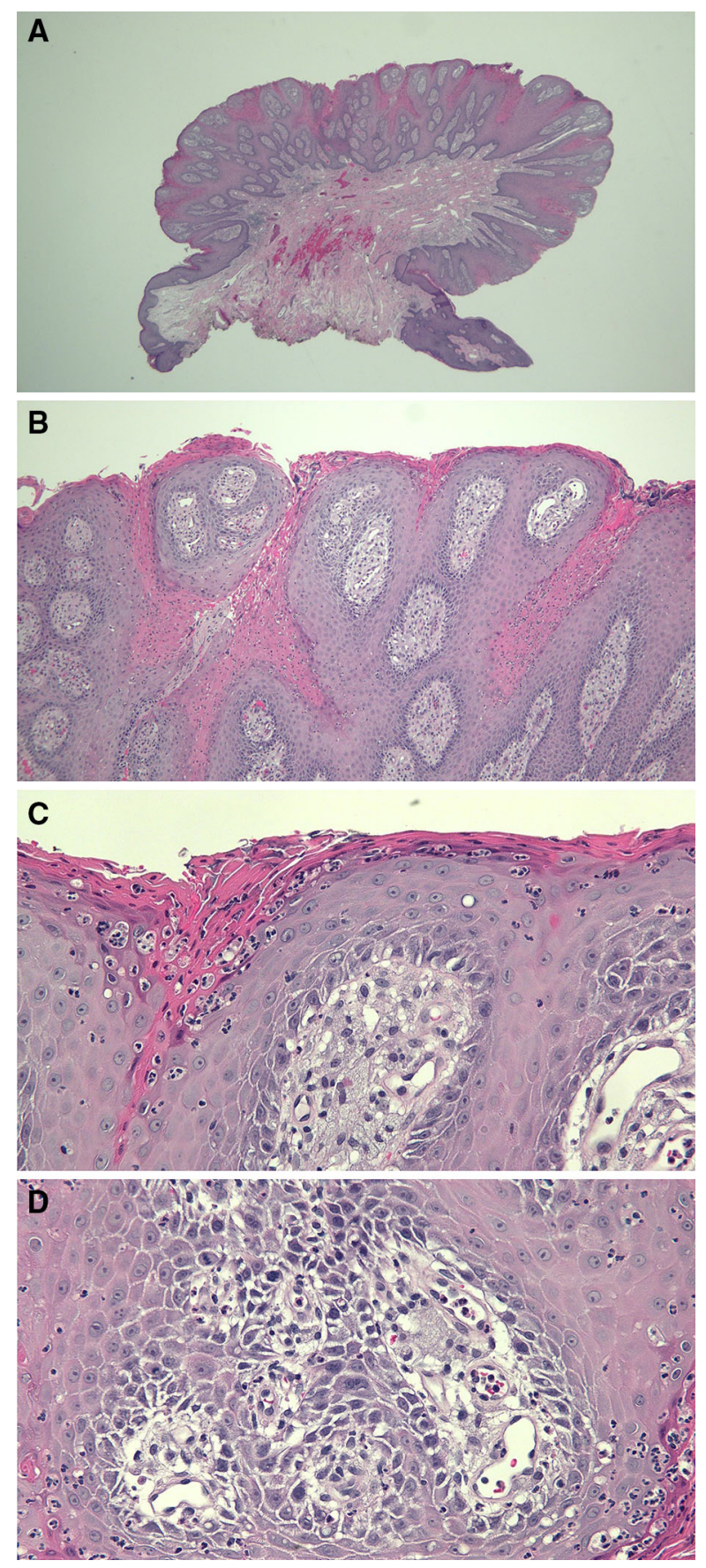

reported on the inguinal folds. The man had a $7 \times 5 \mathrm{~cm}$ well-demarcated plaque on his left inguinal fold that extended over the thigh and onto the scrotum. He also had a $1 \times 2 \mathrm{~cm}$ plaque in the right inguinal fold [69].
4 Fig. 2 Microscopic examination of the lesion from the 83-year-old man was performed. Low magnification (a) shows a pedunculated tumor with acanthosis, papillomatosis, and elongation of the rete ridges. Intermediate magnification $(\mathbf{b}, \mathbf{c})$ reveals parakeratosis and neutrophilic inflammation in the dermis. High magnification (d) reveals numerous foamy histiocytes in the widened dermal papillae. Correlation of the clinical features and the pathologic changes establish a diagnosis of verruciform xanthoma. The lesion was completely removed at the time of biopsy, and the patient applied mupirocin $2 \%$ ointment to the site. The excision site has since completely healed without recurrence. (Hematoxylin and Eosin: $\mathbf{a}=\times 2$, $\mathbf{b}=\times 10, \mathbf{c}=\times 20, \mathbf{d}=\times 40)$

\section{Verruciform Xanthomas of the Female Genitalia (Table 3)}

The first reported extraoral lesions were two cases of verruciform xanthoma of the vulva, described by Santa Cruz and Martin in 1979 [54]. A total of 28 additional vulvar verruciform xanthomas have since been reported in 27 women. Vulvar verruciform xanthomas have been described in a variety of patients, including African American, Chinese, Caucasian, Columbian, and Japanese women.

The age of onset of the female genital lesions ranges from shortly after birth [in association with congenital hemidysplasia with ichthyosiform erythroderma and limb defects (CHILD syndrome)] to age 85 years, with a mean age of 43.2 years. A total of 27 locations have been reported, which included the clitoris $(11.1 \%, n=3)$, external genitalia and groin $(3.7 \%, n=1)$, fourchette $(7.4 \%, n=2)$, genital mucosa $(3.7 \%, n=1)$, inguinal fold $(7.4 \%$, $n=2)$, labia majora $(25.9 \%, n=7)$, labia minora $(18.5 \%, \quad n=5)$, and vulva not otherwise specified $(22.2 \%, n=6)$. The color of the lesion was most commonly yellowish orange.

Vulvar lesions have been found in association with CHILD syndrome 
[44, 47, 49, 52, 59, 60], fibroepithelial polyp [57], leiomyomatosis of uterus [55], lichen planus [43], lichen sclerosus [43, 54], lymphangioma circumscriptum with severe lymphedema [50], radiodermatitis [43], and vulvar Paget's disease [43].

\section{Treatment}

The verruciform xanthomas are cured by complete excision; however, cases of recurrence have been described [13, 43, 76]. One case of recurrence occurred when the lesion was not completely excised [43]. $\mathrm{CO}_{2}$ laser ablation resulted in the recurrence in two cases of vulvar lesions [43, 76]. However, Joo et al. successfully removed a scrotal xanthoma with shave debulking and fractionated $\mathrm{CO}_{2}$ laser ablation [22]. Guo et al. successfully treated a large $(7 \times 5 \mathrm{~mm})$ lesion of the labia minora with imiquiod cream 5\% [51].

\section{CONCLUSION}

Verruciform xanthomas are benign, asymptomatic wart-like lesions most commonly found in the oral cavity. Although they appear similarly to skin lesions caused by tumors or viral infections, they can be distinguished based on histologic evaluation. The defining pathologic features include hyperkeratosis with parakeratosis, acanthosis, elongated rete ridges, neutrophilic inflammation in the dermis, and foam cells in the dermal papillae.

There have been 194 cases of verruciform genital-associated (Vegas) xanthomas reported in the literature. Patients may seek treatment because of concern of a sexually transmitted disease or the lesion may be discovered as an incidental finding during complete cutaneous skin examination. Verruciform xanthomas of the genitalia share similar histologic characteristics with verruciform xanthomas of the oral cavity. The lesions have been reported in association with a variety of cutaneous diseases and systemic conditions.

Verruciform xanthomas are usually asymptomatic and may be present for many years before being treated. Complete surgical excision is the standard method of treatment, and is typically curative. Fractionated $\mathrm{CO}_{2}$ laser therapy and imiquimoid cream have also been used to successfully remove the lesions. Verruciform xanthoma should be considered in the differential diagnosis of an acquired genital tumor.

\section{ACKNOWLEDGEMENTS}

This work was supported by the National Institute on Aging, Grant T35 AG26757 (PI: Dilip V. Jeste, MD), and the Stein Institute for Research on Aging and the Center for Healthy Aging at the University of California, San Diego. All named authors meet the International Committee of Medical Journal Editors (ICMJE) criteria for authorship for this manuscript, take responsibility for the integrity of the work as a whole, and have given final approval for the version to be published.

Disclosures. Katherine M. Stiff and Philip R. Cohen have nothing to disclose.

Compliance with Ethics Guidelines. This article is based on previously conducted studies and does not involve any new studies of human or animal subjects performed by any of the authors.

Data Availability. The datasets during and/ or analyzed during the current study are available from the corresponding author on reasonable request. 
Open Access. This article is distributed under the terms of the Creative Commons Attribution-NonCommercial 4.0 International License (http://creativecommons.org/licenses/ by-nc/4.0/), which permits any noncommercial use, distribution, and reproduction in any medium, provided you give appropriate credit to the original author(s) and the source, provide a link to the Creative Commons license, and indicate if changes were made.

\section{REFERENCES}

1. Arzberger E, Oliveira A, Hofmann-Wellenhof R, Zalaudek I, Cerroni L, Komericki P. Dermoscopy and reflectance confocal microscopy in verruciform xanthoma of the glans penis. J Am Acad Dermatol. 2015;72:e147-9 (PMID 25981017).

2. Joshi R, OVhal A. Verruciform xanthoma: report of five cases. Indian J Dermatol. 2012;57:479-82 (PMID 23248367).

3. Cumberland L, Dana A, Resh B, Fitzpatrick J, Goldenberg G. Verruciform xanthoma in the setting of cutaneous trauma and chronic inflammation: report of a patient and brief review of literature. J Cutan Pathol. 2010;37:895-900 (PMID 19958440).

4. Sinnya S, Wheller L, Carroll M, Williamson R, De'Ambrosis B. Verruciform xanthoma of the penis: a rare Australian case. Australas J Dermatol. 2015;56:e99-101 (PMID 24689840).

5. Cuozzo DW, Vachher P, Sau P, Frishberg DP, James WD. Verruciform xanthoma: a benign penile growth. J Urol. 1995;153:1625-7 (PMID 7714990).

6. Requena L, Sarasa JL, Martin L, Pique E, Farina MC, Olivares M, Escalonilla P. Verruciform xanthoma of the penis with acantholytic cells. Clin Exp Dermatol. 1995;20:504-8 (PMID 8857349).

7. Balus S, Breathnach AS, O'Grady AJ. Ultrastructural observations on 'foam cells' and the source of their lipid in verruciform xanthoma. J Am Acad Dermatol. 1991;24:760-4 (PMID 1869650).

8. Sette CS, Wachholz PA, Brandão LS, Marques GF, Casafus FS, Soares CT. Verruciform xanthoma on the penis: an unusual location. Clin Exp Dermatol. 2015;40:807-8 (PMID 25787016).
9. Ersahin C, Szpaderska AM, Foreman K, Yong S. Verruciform xanthoma of the penis not associated with human papillomavirus infection. Arch Pathol Lab Med. 2005;129:e62-4 (PMID 15737058).

10. Ronan SG, Bolano J, Manaligod JR. Verruciform xanthoma of penis. Light and electron-microscopic study. Urology. 1984;23:600-3 (PMID 6730134).

11. Kraemer BB, Schmidt WA, Foucar E, Rosen T. Verruciform xanthoma of the penis. Arch Dermatol. 1981;117:516-8 (PMID 7259249).

12. Miake S, Nakahara T, Kurihara Y, Hachisuka J, Moroi Y, Furue M. Verruciform xanthoma of the glans penis mimicking squamous cell carcinomarole of scavenger receptor positive macrophages. Eur J Dermatol. 2012;22:391-2 (PMID 22469571).

13. Lora V, Kanitakis J, Bertozzi E, Amantea A, Cota C. Recurrent verruciform xanthoma on a skin autograft of the penis. Eur J Dermatol. 2013;23:905-7 (PMID 24185265).

14. Amantea A, Gaudio E, Catricalà C, Donati P, Balus L. Xantoma verruciforme del pene. G Ital Dermatol Venereol. 1989;124:37-40 (PMID 2767716).

15. Laguna Urraca G, Concha López A, Tudela Patón MP. Xantoma verruciforme de pene. Actas Urol Esp. 1990;14:210-3 (PMID 2122638).

16. Canillot S, Stamm C, Balme B, Perrot H. Xanthome verruciforme du gland. Ann Dermatol Venereol. 1994;121:404-7 (PMID 7702268).

17. Xia TL, Li GZ, Na YQ, Guo YL. Verruciform xanthoma of the penis: report of a case. Chin Med J (Engl). 2004;117:150-2 (PMID 14733794).

18. Mohsin SK, Lee MW, Amin MB, Stoler MH, Eyzaguirre E, Ma CK, Zarbo RJ. Cutaneous verruciform xanthoma: a report of five cases investigating the etiology and nature of xanthomatous cells. Am J Surg Pathol. 1998;22:479-87 (PMID 9537477).

19. Teixeira V, Reis JP, Tellechea Ó, Vieira R, Figueiredo A. Verruciform xanthoma: report of two cases. Dermatol Online J. 2012;18:10 (PMID 22630580).

20. Takiwaki H, Yokota $M$, Ahsan K, Yokota K, Kurokawa Y, Ogawa I. Squamous cell carcinoma associated with verruciform xanthoma of the penis. Am J Dermatopathol. 1996;18:551-4 (PMID 8902105).

21. Ogata D, Tsuchida T. Characteristic dermoscopic features of verruciform xanthoma: report of three cases. J Dermatol. 2015;42:1103-4 (PMID 26211896). 
22. Joo J, Fung MA, Jagdeo J. Successful treatment of scrotal verruciform xanthoma with shave debulking and fractionated carbon dioxide laser therapy. Dermatol Surg. 2014;40:214-7 (PMID 24320039).

23. Ito C, Kitazawac R, Makita K, Watanabe T, Toda A, Haraguchi R, Tanaka S, Kitazawa S. Scrotal cutaneous verruciform xanthoma with monocyte chemoattractant protein-1 immunohistochemical study: a case report. J Med Case Rep. 2012;6:260 (PMID 22937911).

24. Ohnishi T, Shiraishi H, Fukaya S, Tanaka T, Watanabe $S$. Verruciform xanthoma: report of three patients with comparative dermoscopic study. Clin Exp Dermatol. 2015;40:156-9 (PMID 25476138).

25. Fujimoto N, Asano C, Ono K, Tajima S. Verruciform xanthoma results from epidermal apoptosis with galectin-7 overexpression. Eur Acad Dermatol Venereol. 2013;27:922-3 (PMID 22835084).

26. Helm TN, Richards P, Lin L, Helm KF. Verruciform xanthoma with porokeratosis-like features but no clinically apparent lymphedema. J Cutan Pathol. 2012;39:887-8 (PMID 22765052).

27. Gill BJ, Chan AJ, Hsu S. Verruciform xanthoma. Dermatol Online J. 2014;20:12 (PMID 24456956).

28. Kanitakis J, Euvrard S, Butnaru AC, Claudy A. Verruciform xanthoma of the scrotum in a renal transplant patient. Br J Dermatol. 2004;150:161-3 (PMID 14746641).

29. Kishimoto S, Takenaka H, Shibagaki R, Nagata M, Katoh N, Yasuno H. Verruciform xanthoma arising in an arteriovenous haemangioma. Br J Dermatol. 1998;139:546-8 (PMID 9767315).

30. Khaskhely NM, Uezato H, Kamiyama T, Maruno M, Kariya KI, Oshiro M, Nonaka S. Association of human papillomavirus type 6 with a verruciform xanthoma. Am J Dermatopathol. 2000;22:447-52 (PMID 11048983).

31. Yamamoto T, Katayama I, Nishioka K. Verruciform xanthoma in a psoriatic patient under PUVA therapy. Dermatology. 1995;191:254-6 (PMID 8534948).

32. Al-Nafussi AI, Azzopardi JG, Salm R. Verruciform xanthoma of the skin. Histopathology. 1985;9:245-52 (PMID 3988247).

33. Kimura S. Verruciform xanthoma of the scrotum. Arch Dermatol. 1984;120:1378-9 (PMID 6486853).

34. Fukuda H, Saito R. Verruciform xanthoma in close association with isolated epidermolytic acanthoma: a case report and review of the Japanese dermatological literature. J Dermatol. 2005;32:464-8 (PMID 16043921).

35. Takizawa H, Ohnishi T, Watanabe S. Verruciform xanthoma. Report of a case with molecular biological analysis of HPV and immunohistochemical analysis of cytokeratin expression. Clin Exp Dermatol. 2001;26:730-1 (PMID 11722468).

36. Orchard GE, Wilson Jones E, Russel Jones R. Verruciform xanthoma: an immunocytochemical study. Br J Biomed Sci. 1994;51:28-34 (PMID 7841833).

37. Kukreja M, Kamal M, Ray R, Mannan AA. Verruciform xanthoma of the penis in a young male masquerading as squamous cell carcinoma: case report. Gulf J Oncol. 2011;10:65-8 (PMID 21724532).

38. Torrecilla Ortíz C, Marco Perrez LM, Dinares Prat J, Autonell J. Xantoma verruciforme de pene. Actas Urol Esp. 1997;21:797-9 (PMID 9412234).

39. George WM, Azadeh B. Verruciform xanthoma of the penis. Cutis. 1989;44:167-70 (PMID 2758866).

40. Geiss DF, Del Rosso JQ, Murphy J. Verruciform xanthoma of the glans penis: a benign clinical simulant of genital malignancy. Cutis. 1993;51:369-72 (PMID 8513690).

41. Shindo Y, Mikoshiba H, Okamoto K, Morohashi M. Verruciform xanthoma of the scrotum. J Dermatol. 1985;12:443-8 (PMID 3914496).

42. Nakamura S, Kanamori S, Nakayama K, Aoki M. Verruciform xanthoma on the scrotum. J Dermatol. 1989;16:397-401 (PMID 2600278).

43. Fite C, Plantier F, Dupin $N$, Avril MF, Moyal-Barracco M. Vulvar verruciform xanthoma: ten cases associated with lichen sclerosus, lichen planus, or other conditions. Arch Dermatol. 2011;147:1087-92 (PMID 21576553).

44. Gantner S, Rutten A, Requena L, Gassenmaier G, Landthaler $M$, Hafner C. CHILD syndrome with mild skin lesions: histopathologic clues for the diagnosis. J Cutan Pathol. 2014;41:787-90 (PMID 25093865).

45. Lonsdale RN. Verruciform xanthoma of the penis. Br J Urol. 1992;70:574-5 (PMID 1467872).

46. Mehra S, Li L, Fan CY, Smoller B, Morgan M, Somach S. A novel somatic mutation of the 3beta-hydroxysteroid dehydrogenase gene in sporadic cutaneous verruciform xanthoma. Arch Dermatol. 2005;141:1263-7 (PMID 16230564). 
47. Xu XL, Huang LM, Wang Q, Sun JF. Multiple verruciform xanthomas in the setting of congenital hemidysplasia with ichthyosiform Eeythroderma and limb defects syndrome. Pediatr Dermatol. 2015;32:135-7 (PMID 24147604).

48. Sopena J, Gamo R, Iglesias L, Rodriguez-Peralto JL. Disseminated verruciform xanthoma. $\mathrm{Br} J$ Dermatol. 2004;151:717-9 (PMID 15377372).

49. Zamora-Martinez E, Martin-Moreno L, Barat Cascante A, Castro-Torres A. Another CHILD syndrome with xanthomatous pattern. Dermatologica. 1990;180:263-6 (PMID 2358107).

50. Ijichi A, Mitoma C, Yasukochi Y, Uchi H, Furue M. Vulvar verruciform xanthoma developing in acquired lymphangioma circumscriptum. J Dermatol. 2016. doi:10.1111/1346-8138.13490. (Epub ahead of print PMID 27334742).

51. Guo Y, Dang Y, Toyohara JP, Geng S. Successful treatment of verruciform xanthoma with imiquimod. J Am Acad Dermatol. 2013;69:184-6 (PMID 24034392).

52. Barr RJ, Plank CJ. Verruciform xanthoma of the skin. J Cutan Pathol. 1980;7:422-8 (PMID 7451704).

53. Tang R, Kopp SA, Cobb C, Halpern AV. Disseminated verruciform xanthoma: a case report. Cutis. 2014;93:307-10 (PMID 24999643).

54. Santa Cruz DJ, Martin SA. Verruciform xanthoma of the vulva. Report of two cases. Am J Clin Pathol. 1979;71:224-8 (PMID 425938).

55. de Rosa G, Barra E, Gentile R, Boscaino A, Di Prisco B, Ayala F. Verruciform xanthoma of the vulva: case report. Genitourin Med. 1989;65:252-4 (PMID 2807284).

56. Furue M, Suzuki H, Kodama T, Hiramoto T, Sugiyama H, Tamaki K. Colocalization of scavenger receptor in CD68 positive foam cells in verruciform xanthoma. J Dermatol Sci. 1995;10:213-9 (PMID 8593263).

57. Kishimoto S, Takenaka H, Shibagaki R, Nagata M, Yasuno H. Verruciform xanthoma in association with a vulval fibroepithelial polyp. Br J Dermatol. 1997;137:816-20 (PMID 9415249).

58. Leong FJ, Meredith DJ. Verruciform xanthoma of the vulva. A case report. Pathol Res Pract. 1998;194:661-5 (PMID 9793968).

59. Fedda F, Khattab R, Ibrahim A, Hayek S, Khalifeh I. Verruciform xanthoma: a special epidermal nevus. Cutis. 2011;88:269-72 (PMID 22372163).
60. Hashimoto K, Prada S, Lopez AP, Hoyos JG, Escobar M. CHILD syndrome with linear eruptions, hypopigmented bands, and verruciform xanthoma. Pediatr Dermatol. 1998;15:360-6 (PMID 9796585).

61. Minamitsuji Y, Kishi H, Saga K, Masukawa J. A female case of verruciform xanthoma. Jpn J Clin Dermatol. 1996;50:1026-8 (in Japanese).

62. Daimaru Y, Hatano C, Sato S. A case of verruciform xanthoma of the vulva. Jpn J Clin Dermatol. 1997;51:733-5 (in Japanese).

63. Beutler BD, Cohen PR. Verruciform genital-associated xanthoma: report of patient with verruciform xanthoma of the scrotum and literature review. Dermatol Online J. 2015;21:1087-2108 (PMID 26437158).

64. Shafer WG. Verruciform xanthoma. Oral Surg Oral Med Oral Pathol. 1971;31:784-9 (PMID 5280461).

65. Griffel B, Cordoba M. Verruciform xanthoma in the anal region. Am J Proctol Gastroenterol Colon Rectal Surg. 1980;31:24-5 (PMID 7386619).

66. Jensen JL, Liao SY, Jeffes EW. Verruciform xanthoma of the ear with coexisting epidermal dysplasia. Am J Dermatopathol. 1992;14(5):426-30 (PMID: 1329573).

67. Blankenship DW, Zech L, Mirzabeigi M, Venna S. Verruciform xanthoma of the upper-extremity in the absence of chronic skin disease or syndrome: a case report and review of the literature. J Cutan Pathol. 2013;40(8):745-52 (PMID:23656213).

68. Mountcastle EA, Lupton GP. Verruciform xanthoma of the digits. J Am Acad Dermatol. 1989;20:313-7 (PMID:2644320).

69. Connoly SB, Lewis EJ, Lindholm JS, Zelickson BD, Zachary CB, Tope WD. Management of cutaneous verruciform xanthoma. J Am Acad Dermatol. 2000;42:343-7 (PMID 10640929).

70. Huguet P, Toran N, Tarragona J. Cutaneous verruciform xanthoma arising on a congenital lymphoedematous leg. Histopathology. 1995;26(3):277-9 (PMID: 7797206).

71. Than T, Birch PJ, Dawes PJ. Verruciform xanthoma of the nose. J Laryngol Otol. 1999;113(1):79-81 (PMID: 10341929).

72. Zhou H. Verruciform xanthoma of the glans penis: report of a case. Zhonghua Bing Li Xue Za Zhi. 2012;41:127. (PMID 22455893 in Chinese).

73. Allen CM, Kapoor N. Verruciform xanthomai $\mathrm{n}$ a bone marrow transplant recipient. Oral Surg Oral Med Oral Pathol. 1993;75:591-4 (PMID 8488027). 
74. Cooper TW, Santa Cruz DJ, Bauer EA. Verruciform xanthoma. Occurrence in eroded skin in a patient with recessive dystrophic epidermolysis bullosa. J Am Acad Dermatol. 1983;8:463-7 (PMID 6853779).

75. Frankel MA, Rhodes HE, Euscher ED. Verruciform xanthoma in an adolescent: a case report. J Low Genit Tract Dis. 2012;16:70-4 (PMID 22126832).

76. Reich O, Regauer S. Recurrent verruciform xanthoma of the vulva. Int J Gynecol Pathol. 2004;23:75-7 (PMID 14668556).

77. Pellice C Jr, Sole M, Pellice C, Carretero P. Verruciform xanthoma of the penis. J Urol (Paris). 1987;93:41-2 (PMID 3559260).

78. Sachs O. Beitrage zur histologie der weichen naevi. Archiv Dermatol Syphillis. 1903;66:101-26. (No PMID).

79. Philipsen HP, Reichart PA, Takata T, Ogawa I. Verruciform xanthoma-biological profilfe of 282 oral lesions based on a literature survey with nine new cases from Japan. Oral Oncol. 2003;39:325-36 (PMID 12676251).

80. Kono Y. Verruciform xanthoma. Hifu Rinsho. 1985;27:1082-83. (No PMID).

81. Zegarelli DJ, Zegarelli-Schmidt EC, Zegarelli EV. Verruciform xanthoma. Further light and electron microscopic studies, with the addition of a third case. Oral Surg Oral Med Oral Pathol. 1975;40:246-56.

82. Travis WD, Davis GE, Tsokos M, Lebovics R, Merrick HF, Miller SP, Gregg RE, Di Bisceglie AM, Parker RI, Ishak KG, et al. Multifocal verruciform xanthoma of the upper aerodigestive tract in a child with systemic lipid storage disease. Am J Surg Pathol. 1989;13:309-16 (PMID 2539022).

83. Helm KF, Höpfl RM, Kreider JW, Lookingbill DP. Verruciform xanthoma in an immunocompromised patient: a case report and immunohistochemical study. J Cutan Pathol. 1991;20:84-6 (PMID 8385681).

84. Oliveira PT, Jaeger RG, Cabral LA, Carvalho YR, Costa AL, Jaegar MM. Verruciform xanthoma of the oral mucosa. Report of four cases and a review of the literature. Oral Oncol. 2001;37:326-31 (PMID 11287290).

85. Miyamoto Y, Nagayama M, Hayashi Y. Verruciform xanthoma occurring within oral lichen planus. J Oral Pathol Med. 1996;25:188-91 (PMID 8809688).

86. Mostafa KA, Takata T, Ogawa I, Ijuhin N, Nikai H. Verruciform xanthoma of the oral mucosa: a clincopathological study with immunohistochemical findings related to pathogenesis. Virchows Arch A. 1993;423:243-8 (PMID 8236821). 